\title{
Rhizoma Pinelliae trypsin inhibitor separation, purification and inhibitory activity on the proliferation of BGC-823 gastric adenocarcinoma cells
}

\author{
GUOHONG ZU ${ }^{1}$, HOUWEI WANG ${ }^{2}$, JIE WANG ${ }^{3}$, YAN DOU ${ }^{1}$, WEICHONG ZHAO ${ }^{1}$ and YUPING SUN ${ }^{1}$ \\ ${ }^{1}$ Department of Radiation Oncology, Jinan Central Hospital Affiliated to Shandong University; \\ ${ }^{2}$ Department of Chinese Pharmacy, Shandong University of Traditional Chinese Medicine; \\ ${ }^{3}$ Department of Surgery, Jinan Central Hospital Affiliated to Shandong University, \\ Jinan, Shandong 250013, P.R. China
}

Received October 9, 2013; Accepted February 18, 2014

DOI: 10.3892/etm.2014.1701

\begin{abstract}
The aim of this study was to isolate and purify Rhizoma Pinelliae trypsin inhibitor (RPTI), determine its N-terminal amino acid sequence and evaluate its inhibitory effect on the proliferation of poorly differentiated BGC-823 human gastric adenocarcinoma cells. RPTI was separated and purified from a $40 \%\left(\mathrm{NH}_{4}\right)_{2} \mathrm{SO}_{4}$ precipitate of crude protein extract of Pinellia ternata tuber using affinity chromatography with trypsin as the ligand. The N-terminal amino acid sequence of RPTI was determined using the Edman degradation method. The inhibitory effect of RPTI on BGC-823 cell proliferation was detected in vitro using the MTT method and in vivo in tumour-bearing mice. The purified RPTI showed a single band under SDS-PAGE, its molecular weight was $14 \mathrm{kDa}$ and its $\mathrm{N}$-terminal amino acid sequence was DPVVDG. RPTI inhibited trypsin activity, with an inhibition ratio of 1:6.78 (mass). RPTI significantly inhibited the proliferation of BGC-823 cells in vitro. The $\mathrm{IC}_{50}$ of $\mathrm{RPTI}$ was $16.96 \mu \mathrm{g} / \mathrm{ml}$ within $48 \mathrm{~h}$ after treatment and $9.61 \mu \mathrm{g} / \mathrm{ml}$ within $72 \mathrm{~h}$ after treatment. Subcutaneous injection of RPTI around the tumour significantly inhibited BGC-823 tumour growth in mice. The tumour inhibitory effect was concentration- and dose-dependent. RPTI did not significantly influence the spleen coefficient of the mice. In conclusion, RPTI is a serine proteinase inhibitor with antitumour activity.
\end{abstract}

Correspondence to: Professor Guohong $\mathrm{Zu}$, Department of Radiation Oncology, Jinan Central Hospital Affiliated to Shandong University, 105 Jiefang Road, Jinan, Shandong 250013, P.R. China E-mail: guohongzucn@163.com

Key words: Pinellia, trypsin inhibitor, human poorly differentiated gastric adenocarcinoma

\section{Introduction}

The traditional Chinese herbal medicine Rhizoma Pinelliae (RP) is the tuber of Pinellia ternata (Thunb.) Breit., and is listed in the Dictionary of Traditional Chinese Medicine (1) as effective in removing dampness to reduce phlegm, reducing adverse qi for controlling nausea and vomiting, and relieving distension to eliminate stagnation, among other effects (2-4). $\mathrm{RP}$ is used alone or in combination with other Chinese medicines to treat various neoplastic diseases. This plant is also used as folk medicine for treating cancer in several regions of China (5-8). There have been a number of studies on the antitumour activity of Pinellia, such as the inhibitory effects of ethanolic Pinellia extract on liver cancer cells, of total organic acids of Pinellia on gastric cancer cells and of Pinellia protein on ovarian cancer cells (8-12). However, to the best of our knowledge, the antitumour activity of low molecular weight components of Pinellia has not been reported. Trypsin inhibitors (TIs), low molecular weight proteins that inhibit various serine proteinases, are widely present in animals, plants and microorganisms. TIs inhibit the catalytic activity of enzymes or prevent zymogen activation through combination with the active and allosteric site of the proteinase. TIs are crucial in regulating physiological and pathological processes and are an important component of the immune system. TIs have extensive application prospects in the research and development of antitumour drugs (13-18). Studies have demonstrated that TI receptors are present in numerous types of tumour cell, and TIs exert their antitumour function by binding with the receptors and regulating the activity of related proteinases (19-26). In the present study, we isolated a small water-soluble protein from Pinellia ternata, investigated its trypsin inhibitory activity and considered the association of antitrypsin activity with antitumour activity. The present study aimed to isolate and purify short-chain peptides with serine proteinase inhibitory activity from the small water-soluble protein components of raw RP, and to study their physicochemical properties and their ability to inhibit the proliferation of poorly differentiated BGC-823 human gastric adenocarcinoma cells in vivo and in vitro. 


\section{Materials and methods}

Animals. Specific pathogen-free BALB/c nude mice were provided by the Experimental Animal Centre at Shandong University of Traditional Chinese Medicine (Jinan, China). This study was carried out in strict accordance with the recommendations in the Guide for the Care and Use of Laboratory Animals of the National Institutes of Health (2010, Eighth edition). The animal use protocol was reviewed and approved by the Institutional Animal Care and Use Committee of Shandong University (Jinan, China).

Extraction and separation of RPTI. Fresh Pinellia ternata tuber (100 g; ChengWu pinellia planting base, Heze, China) was washed, homogenised in 10-fold its volume of buffer solution for extraction $(0.05 \mathrm{~mol} / 1, \mathrm{pH} 8.0$, Tris $\mathrm{HCl})$ and centrifuged (4,650 x g, $10 \mathrm{~min})$. After rinsing off the floating solid fatty materials, the supernatant was collected and then lyophilised using a lyophiliser (FD-1D-50; Shanghai Bilon Instrument Co., Ltd., Shanghai, China) to obtain the lyophilised crude RP protein powder. The powder was weighed and its TI activity was detected.

The lyophilised powder was redissolved in an appropriate amount of buffer solution for extraction using the stepwise salting-out method. $\left(\mathrm{NH}_{4}\right)_{2} \mathrm{SO}_{4}$ with 40,60 and $80 \%$ degrees of saturation was gradually added to the solution, which was left to stand at $4^{\circ} \mathrm{C}$ for $2 \mathrm{~h}$ and then centrifuged $(8,000 \mathrm{rpm}$, $10 \mathrm{~min})$. The precipitate from all steps was collected and dialysed with distilled water at $4^{\circ} \mathrm{C}$ for $36 \mathrm{~h}$; during the dialysis, the dialysate was replaced nine times and the molecular weight of the proteins retained by the dialysis bag was $\geq 6,000 \mathrm{Da}$ (Pharmacia Biotech). After centrifuging (8,000 rpm, $10 \mathrm{~min}$ ), the supernatant was lyophilised and weighed. The TI activity was detected and the dialysed and lyophilised $\left(\mathrm{NH}_{4}\right)_{2} \mathrm{SO}_{4}$ precipitate with the highest activity was designated as the crude RPTI product.

Protein content determination. The protein content was determined using the Lowry protein assay method with bovine serum albumin (Sigma-Aldrich, St. Louis, MO, USA) as the standard (27).

Preparation of the affinity carrier. CNBr-activated Sepharose CL-4B (Pharmacia Biotech, Stockholm, Sweden) was coupled with an appropriate amount of trypsin to prepare the affinity carrier based on the manufacturer's instructions (2010).

RPTI purification. The crude RPTI product $(20 \mathrm{mg})$ was dissolved in $200 \mathrm{ml}$ balanced buffer solution $(0.05 \mathrm{~mol} / \mathrm{l}$, $\mathrm{pH} 8.0$, Tris $\mathrm{HCl})$ and centrifuged $\left(4^{\circ} \mathrm{C}, 10,464 \mathrm{x} \mathrm{g}, 10 \mathrm{~min}\right)$. Following maintenance of the supernatant in the affinity column at $37^{\circ} \mathrm{C}$ for $1 \mathrm{~h}$, the column was washed with balanced buffer solution containing $1 \mathrm{~mol} / \mathrm{l} \mathrm{NaCl}$, distilled water and hydrochloric acid solution at $\mathrm{pH}$ 2.4. The eluent of the acid solution was collected and was immediately neutralised dropwise with $2.0 \mathrm{~mol} / 1$ Tris. Following repeated sample loading, the eluent was combined and directly filtered with a Sephadex G-50 chromatographic column (Pharmacia Biotech) and with $0.05 \mathrm{~mol} / \mathrm{l}$ Tris $\mathrm{HCl}$ buffer solution (pH 8.0) as the eluent. The trypsin inhibition activity peak was determined and the protein purity of the activity peak in each tube was detected with SDS-PAGE. The SDS-PAGE index was based on the literature (28). The gel concentration was $12 \%$ and Coomassie Brilliant Blue R-250 was used for staining.

RPTI sequencing. The N-terminal amino acid sequence of RPTI was performed by Kang Biotechnology Compnay of Shanghai (Shanghai, China) using the Edman degradation method with an ABI 491A amino acid sequencer (Applied Biosystems, Foster City, CA, USA) (29).

Determination of TI activity. Based on the literature (30), trypsin activity (Sigma-Aldrich) and TI activity were detected using BAPNA (Sigma-Aldrich) as the substrate. The sample to be tested was dissolved in $0.80 \mathrm{ml}$ Tris $\mathrm{HCl}$ buffer solution $(0.05 \mathrm{~mol} / 1, \mathrm{pH} 8.0), 0.20 \mathrm{ml}$ bovine trypsin $(0.10 \mathrm{mg} / \mathrm{ml})$ was added and the system was maintained at $37^{\circ} \mathrm{C}$ for $5 \mathrm{~min}$. Subsequently, $2.50 \mathrm{ml}$ BAPNA solution $(1 \mathrm{mmol} / \mathrm{l})$ was added, the system was maintained at $37^{\circ} \mathrm{C}$ for $5 \mathrm{~min}$ and then $0.5 \mathrm{ml}$ $33 \%$ acetic acid was immediately added to terminate the reaction. The absorbance (A) was detected at $410 \mathrm{~nm}$, with the test sample without inhibitor as the control sample. One unit of enzyme activity was defined as the amount of enzyme required to increase A410 by 0.01, whereas one unit of RPTI-inhibitory activity was defined as the amount of enzyme required to decrease A410 by 0.01 .

Cell culture. Dulbecco's modified Eagle's medium (DMEM) (Gibco-BRL, Carlsbad, CA, USA) was formulated based on the product description, adjusted to $\mathrm{pH}$ 7.2-7.4 with $0.1 \mathrm{~mol} / 1$ hydrochloric acid and maintained at $4^{\circ} \mathrm{C}$. The foetal bovine serum was deactivated at $56^{\circ} \mathrm{C}$ for $30 \mathrm{~min}$ and then maintained at $-20^{\circ} \mathrm{C}$. Trypsin was diluted to a $2.5 \mathrm{~g} / 1$ solution with $0.01 \mathrm{~mol} / 1$ phosphate-buffered saline (PBS) at $\mathrm{pH} 7.4$ and then maintained at $4^{\circ} \mathrm{C}$. The poorly differentiated BGC- 823 human gastric adenocarcinoma cells (Chinese medicine biotechnology laboratory of Shandong Traditional Chinese Medicine University) were incubated in DMEM containing 10\% refined calf serum (Gibco-BRL), $100 \mathrm{U} / \mathrm{ml}$ penicillin and $100 \mu \mathrm{g} / \mathrm{ml}$ streptomycin under a $5 \% \mathrm{CO}_{2}$ atmosphere at $37^{\circ} \mathrm{C}$ and were subcultured following trypsinisation when the BGC-823 cells adhered to the walls of the flask.

MTT method. Based on the literature (31), $5 \mathrm{~g} / 1 \mathrm{MTT}$ (Sigma-Aldrich) solution was formulated with normal saline, sterilised through filtration with a $0.22-\mu \mathrm{m}$ filter (Millipore, Billerica, MA, USA), subpacked and then maintained at $4^{\circ} \mathrm{C}$. The BGC-823 cells in the logarithmic phase were inoculated into 96 -well plates at a density of $1 \times 10^{5}$ cells $/ \mathrm{ml}$ and with $100 \mu \mathrm{l} /$ well and treated following culture for $24 \mathrm{~h}$. Five RPTI concentrations were established: $32,16,8,4$ and $2 \mu \mathrm{g} / \mathrm{ml}$ and six dual wells were established for each dose. At 48 and $72 \mathrm{~h}$ after treatment, three dual wells were selected and the culture supernatant was discarded through aspiration from the wells. Each well was washed with PBS once and then the supernatant was removed through aspiration. Subsequently, $100 \mu \mathrm{l}$ complete DMEM and $10 \mu \mathrm{l}$ MTT solution were added into each well and the plates were incubated for $4 \mathrm{~h}$ at $37^{\circ} \mathrm{C}$ under a saturated $5 \% \mathrm{CO}_{2}$ atmosphere. The culture was 
Table I. Isolation of RPTI crude protein by salt fractionation with $\left(\mathrm{NH}_{4}\right)_{2} \mathrm{SO}_{4}$ and determination of its inhibitory activity.

\begin{tabular}{lcccr}
\hline Component & $\begin{array}{c}\text { Total protein } \\
(\mathrm{mg})\end{array}$ & $\begin{array}{c}\text { Total inhibitory activity } \\
(\mathrm{U})\end{array}$ & $\begin{array}{c}\text { Inhibition recovery } \\
(\%)\end{array}$ & $\begin{array}{c}\text { Specific inhibitory activity } \\
(\mathrm{U} / \mathrm{mg})\end{array}$ \\
\hline Total protein & 362.33 & 34750 & 100.00 & 95.91 \\
$40 \%\left(\mathrm{NH}_{4}\right)_{2} \mathrm{SO}_{4}$ precipitate & 123.67 & 21677 & 62.38 & 175.81 \\
$60 \%\left(\mathrm{NH}_{4}\right)_{2} \mathrm{SO}_{4}$ precipitate & 205.14 & 9883 & 28.44 & 48.18 \\
$80 \%\left(\mathrm{NH}_{4}\right)_{2} \mathrm{SO}_{4}$ precipitate & 20.81 & 0 & 0.00 & 0.00 \\
Total $\left(\mathrm{NH}_{4}\right)_{2} \mathrm{SO}_{4}$ precipitate & 349.62 & 31560 & 90.82 & 90.27 \\
\hline
\end{tabular}

RPTI, Rhizoma Pinelliae trypsin inhibitor.

then terminated and the cultural supernatant was carefully discarded by aspiration from the wells. Dimethylsulphoxide $(150 \mu \mathrm{l})$ was added into each well and agitated for $10 \mathrm{~min}$ for full dissolution. The absorbance at $490 \mathrm{~nm}$ was determined with an enzyme-labelled instrument (3550 microplate reader; Bio-Rad, Hercules, CA, USA) to compute the cell growth inhibition rate according to the following formula: cell growth inhibition rate $(\%)=(1-$ average $\mathrm{A}$ of the treatment group)/average $\mathrm{A}$ of the control group $\mathrm{x} 100]$. The $\mathrm{IC}_{50}$ of RPTI was calculated using SPSS software, version 13.0 (SPSS, Inc., Chicago, IL, USA).

Determination of in vivo antitumour activity. BGC-823 cells in the logarithmic phase were washed twice with DMEM and then resuspended in DMEM at a density of $1 \times 10^{6}$ cells $/ \mathrm{ml}$. Subsequently, $0.1 \mathrm{ml}$ of the cell suspension, i.e., $1 \times 10^{5}$ BGC-823 cells, was subcutaneously (SC) injected into the back of each BALB/C-nu mouse. Five mice were inoculated, which were regularly observed and fed. After 20 days, the mice were sacrificed, the tumours were dissected and their fibrous capsules were removed. The well-grown tumour tissues were selected, cut into $1-\mathrm{mm}^{3}$ sections (weighing $\sim 40 \mathrm{mg}$ ) and added to $0.2 \mathrm{ml}$ normal saline. One section of the tumour tissue was transplanted into the left axilla of each nude mouse. The following day, the inoculated nude mice were randomly assigned into three groups, with 10 mice in each group: The control group (SC injection of normal saline at $10 \mathrm{ml} / \mathrm{kg}$ once daily); the cyclophosphamide (CTX) group (SC injection of CTX around the tumour at $20 \mathrm{mg} / \mathrm{kg}$ once every two days); and the RPTI groups (SC injection of RPTI at 250, 50 and $10 \mathrm{mg} / \mathrm{kg}$ once daily). The treatments were administered for 12 consecutive days. One day after completing the treatments, the mice were weighed and then sacrificed through cervical dislocation. The subcutaneous tumours were dissected and the tumour weights among the groups were compared. The tumour inhibition rate was then calculated. The spleen was collected under sterile conditions and weighed to determine the spleen coefficient: Spleen coefficient $=$ spleen weight (mg)/body weight (g).

Statistical analysis. The different RPTI treatment groups were compared using SPSS software, a homogeneity test of variance and a t-test. The data were expressed as the mean \pm standard deviation. $\mathrm{P}<0.05$ was considered to indicate a statistically significant result.

\section{Results}

RPTI extraction and separation. Fresh Pinellia ternata tuber was ground, homogenised, aqueously extracted and lyophilised to obtain a water-soluble lyophilised protein powder. $\left(\mathrm{NH}_{4}\right)_{2} \mathrm{SO}_{4}$ precipitates of the total protein of Pinellia ternata at all levels were obtained by further using the stepwise salting-out method. The total recovery rate of the precipitate was $96.49 \%$. Analysis indicated that TI activity was mainly concentrated in the $40 \%\left(\mathrm{NH}_{4}\right)_{2} \mathrm{SO}_{4}$ precipitate and the specific trypsin inhibitory activity was 1.83 -fold that of the total protein; the recovery of inhibitory activity was $62.38 \%$ and the total protein content of the precipitate was $123.67 \mathrm{mg}$, accounting for $34.13 \%$ of the total protein. The majority of the protein precipitated with $60 \%\left(\mathrm{NH}_{4}\right)_{2} \mathrm{SO}_{4}$, accounting for $56.62 \%$ of the total protein, and it had partial TI activity; its specific activity was only 0.50 -fold that of the total protein. The $80 \%\left(\mathrm{NH}_{4}\right)_{2} \mathrm{SO}_{4}$ solution precipitated the least amount of protein, which exhibited no TI activity (Table I).

RPTI purification. The $40 \%\left(\mathrm{NH}_{4}\right)_{2} \mathrm{SO}_{4}$ precipitate was designated as the crude RPTI product and subjected to trypsin-Sepharose 4B affinity chromatography to form two protein peaks $\left(\mathrm{A}_{280 \mathrm{~nm}}\right.$; Fig. $\left.1 \mathrm{~A}\right) . \mathrm{P}_{1}$ was a saliferous elution peak that exhibited no TI activity and $\mathrm{P}_{2}$ was an affinity adsorption activity peak, which was further separated using Sephadex G-50 to form four protein peaks (Fig. 1B). The $P_{1}$ and $\mathrm{P}_{2}$ formed by Sephadex G-50 separation were TI activity peaks, which were mainly concentrated in tubes 10-16. The $12 \%$ SDS-PAGE purity detection indicated that only the components in tubes 10-12 (the first half of $\mathrm{P}_{1}$ ) exhibited a single protein band and were estimated to have $>90 \%$ purity. The eluents of the samples in tubes 10-12 following repeated sample loading were collected and combined to obtain purified RPTI. Fig. 1C shows that the crude RPTI protein had numerous bands and a complex composition. Further affinity chromatography removed the majority of the hybrid proteins and only left two clear main bands. More uniform main bands of RPTI were obtained following the gel filtration, with an apparent relative molecular weight of $\sim 14 \mathrm{kDa}$. The activity recovery during each purification step is listed in Table II. Following the affinity chromatography, the specific inhibitory activity increased by 3.45 -fold. The Sephadex G-50 separation produced a homogenous component. The activity recovery was $24.40 \%$ and 6.02-fold purified RPTI was obtained. 
Table II. Purification steps of RPTI.

\begin{tabular}{lcccc}
\hline Purification step & $\begin{array}{c}\text { Total protein } \\
(\mathrm{mg})\end{array}$ & $\begin{array}{c}\text { Total inhibition activity } \\
(\mathrm{U})\end{array}$ & $\begin{array}{c}\text { Specific inhibition activity } \\
\left(\mathrm{U} / \mathrm{mg}^{-1}\right)\end{array}$ & $\begin{array}{c}\text { Inhibition recovery } \\
(\%)\end{array}$ \\
\hline $40 \%\left(\mathrm{NH}_{4}\right)_{2} \mathrm{SO}_{4}$ precipitate & 20.00 & 3516.20 & 175.81 & 100.00 \\
Affinity chromatography & 2.19 & 1326.50 & 605.71 & 37.73 \\
Sephadex G-50 gel filtration & 0.81 & 857.80 & 1059.01 & 24.40
\end{tabular}

RPTI, Rhizoma Pinelliae trypsin inhibitor.

Table III. N-terminal amino acid sequence of five protease inhibitors and their homology comparison results.

\begin{tabular}{llcr}
\hline ID & \multicolumn{1}{c}{ Name } & N-terminal amino acid sequence & Homology $(\%)$ \\
\hline This study & RPTI & 1 DPVVDG 6 & $5 / 6(83.33)$ \\
BAA02972.1 & Precursor of arrowhead proteinase inhibitor A & 25 DPVVDS 30 & $5 / 6(83.33)$ \\
BAA02973.1 & Precursor of arrowhead proteinase inhibitor B & 25 DPVVDS 30 & $5 / 6(83.33)$ \\
1818181A & Arrowhead proteinase inhibitor A & 1 DPVVDS 6 & $5 / 6(83.33)$ \\
1208229A & Arrowhead proteinase inhibitor B & 1 DPVVDS 6 & $5 / 6(83.33)$
\end{tabular}

RPTI, Rhizoma Pinelliae trypsin inhibitor.

A

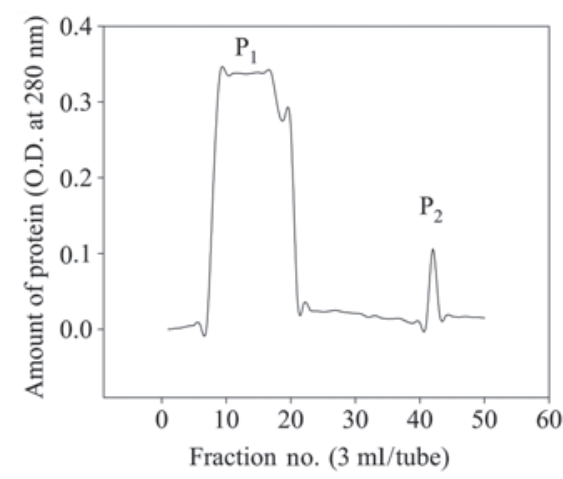

$\mathbf{B}$

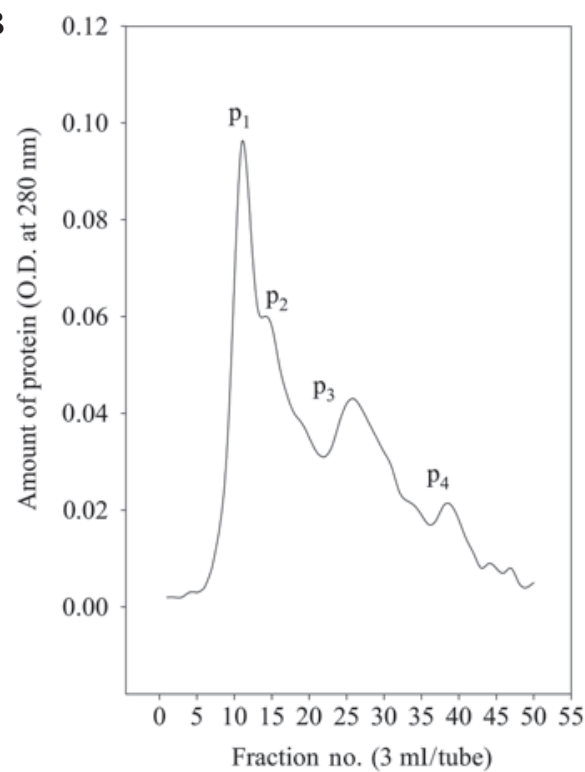

C

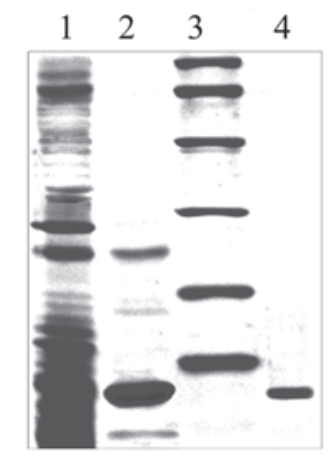

Figure 1. Separation, purification and electrophoresis of RPTI. (A) Sepharose 4B trypsin-affinity chromatography. (B) Sephadex G-50 gel filtration chromatography. (C) SDS-PAGE of RPTI: Lane 1, $40 \%\left(\mathrm{NH}_{4}\right)_{2} \mathrm{SO}_{4}$ precipitation; 2, affinity chromatography; 3, molecular weight markers (from top to bottom: 97.4 , 66.2, 43.0, 31.0, 20.1 and 14.4 kDa); and 4, gel filtration. OD, optical density; RPTI, Rhizoma Pinelliae trypsin inhibitor.

$N$-terminal amino acid sequence and homology. Following SDS-PAGE and the transmembrane filtration, the N-terminal amino acid sequence of the pure RPTI was determined. The first six amino acid residues at the N-terminal of the RPTI in the present study were 1-DPVVDG-6. The BLAST database of the NCBI indicated that the first six amino acids in the $\mathrm{N}$-terminal sequence of RPTI are the same as those of arrowhead proteinase inhibitors $\mathrm{A}$ and $\mathrm{B}$, with serine replacing glycine at the sixth position being the only difference. The
RPTI sequence was highly homologous to those of the arrowhead proteinase inhibitors (>80\%; Table III).

Inhibitory effect of RPTI on trypsin activity. A $10-\mu \mathrm{g} / \mathrm{ml}$ RPTI solution was formulated with $0.05 \mathrm{~mol} / 1$ Tris $\mathrm{HCl}(\mathrm{pH} \mathrm{8.0)}$ buffer solution and successively diluted to 5.00, 2.50, 1.25 and $0.625 \mu \mathrm{g} / \mathrm{ml}$. The inhibitory activity of RPTI on trypsin was determined using the following method: $0.80 \mathrm{ml}$ diluted sample solution under test is added to $0.20 \mathrm{ml}$ bovine trypsin 
Table IV. Inhibitory activity of RPTI on trypsin.

\begin{tabular}{lccc}
\hline $\begin{array}{l}\text { RPTI concentration } \\
(\mu \mathrm{g} / \mathrm{ml})\end{array}$ & $\begin{array}{c}\mathrm{A} 410 \mathrm{~nm} \\
(\text { mean } \pm \mathrm{SD}, \mathrm{n}=3)\end{array}$ & $\begin{array}{c}\text { Residual enzyme activity } \\
(\%)\end{array}$ & $\begin{array}{c}\text { Enzyme activity inhibition rate } \\
(\%)\end{array}$ \\
\hline 0.000 & $0.218 \pm 0.014$ & 100.00 & 0.00 \\
0.625 & $0.166 \pm 0.017^{\mathrm{a}}$ & 76.15 & 23.85 \\
1.250 & $0.123 \pm 0.013^{\mathrm{a}}$ & 56.42 & 43.58 \\
2.500 & $0.075 \pm 0.01^{\mathrm{a}}$ & 34.40 & 65.60 \\
5.000 & $0.047 \pm 0.009^{\mathrm{a}}$ & 21.56 & 78.44 \\
\hline
\end{tabular}

${ }^{\mathrm{a}} \mathrm{P}<0.01$, compared with the control group. RPTI, Rhizoma Pinelliae trypsin inhibitor.

Table V. Inhibitory effect of RPTI on the in vitro proliferation of BGC-823 cells.

$48 \mathrm{~h}$ after addition of RPTI

\begin{tabular}{|c|c|c|c|c|}
\hline \multirow[b]{2}{*}{ RPTI $(\mu \mathrm{g} / \mathrm{ml})$} & & \\
\hline & Absorbance (A) & Inhibition rate (\%) & Absorbance (A) & Inhibition rate (\%) \\
\hline 0 & $0.163 \pm 0.014$ & - & $0.178 \pm 0.017$ & - \\
\hline 2 & $0.147 \pm 0.001$ & 9.82 & $0.152 \pm 0.013^{\mathrm{a}}$ & 14.42 \\
\hline 4 & $0.131 \pm 0.007^{\mathrm{a}}$ & 19.63 & $0.132 \pm 0.011^{\mathrm{a}}$ & 25.78 \\
\hline 8 & $0.109 \pm 0.008^{\mathrm{a}}$ & 33.13 & $0.099 \pm 0.009^{\mathrm{a}}$ & 44.26 \\
\hline 16 & $0.082 \pm 0.006^{\mathrm{a}}$ & 49.69 & $0.060 \pm 0.007^{\mathrm{a}}$ & 66.53 \\
\hline 32 & $0.059 \pm 0.005^{\mathrm{a}}$ & 63.80 & $0.037 \pm 0.008^{\mathrm{a}}$ & 79.04 \\
\hline
\end{tabular}

Absorbance values are the mean $\pm \mathrm{SD}, \mathrm{n}=10$. ${ }^{\mathrm{a}} \mathrm{P}<0.01$, compared with the control $(0 \mu \mathrm{g} / \mathrm{ml})$ group. RPTI, Rhizoma Pinelliae trypsin inhibitor.

Table VI. Tumour inhibition rate of RPTI on BGC-823 cells in tumour-bearing mice and the spleen coefficient.

\begin{tabular}{lcccc}
\hline Group & $\begin{array}{c}\text { Dose } \\
(\mathrm{mg} / \mathrm{kg})\end{array}$ & $\begin{array}{c}\text { Tumour weight } \\
(\mathrm{g})\end{array}$ & $\begin{array}{c}\text { Tumour inhibition rate } \\
(\%)\end{array}$ & $\begin{array}{c}\text { Spleen coefficient } \\
(\mathrm{mg} / \mathrm{g})\end{array}$ \\
\hline Control & - & $1.44 \pm 0.26$ & 0.00 & $5.64 \pm 0.83$ \\
CTX & 20 & $0.28 \pm 0.08^{\mathrm{a}}$ & 80.56 & $5.25 \pm 0.75$ \\
High dose of RPTI & 250 & $0.41 \pm 0.11^{\mathrm{a}}$ & 71.53 & $5.83 \pm 1.06$ \\
Medium dose of RPTI & 50 & $0.96 \pm 0.19^{\mathrm{a}}$ & 33.33 & $5.78 \pm 0.96$ \\
Low dose of RPTI & 10 & $1.18 \pm 0.23$ & 18.06 & $5.67 \pm 0.87$ \\
\hline
\end{tabular}

Conducted in triplicate. Tumour weight and spleen coefficient values are the mean $\pm \mathrm{SD}$. ${ }^{\mathrm{a}}<0.01$, compared with the control group. RPTI, Rhizoma Pinelliae trypsin inhibitor; CTX, cyclophosphamide.
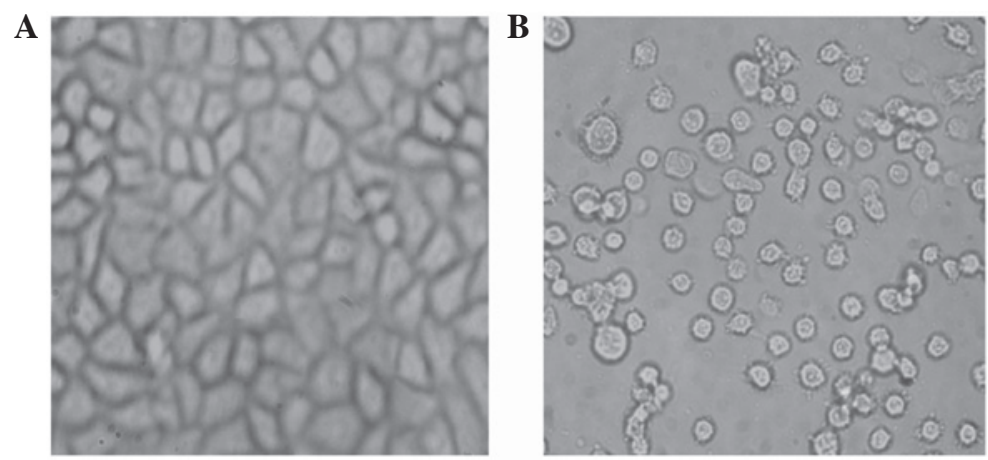

Figure 2. Influence of RPTI on BGC-823 cell shape (magnification, x100). (A) Control; (B) RPTI treatment (10 $\mu \mathrm{g} / \mathrm{ml} \mathrm{RPTI}, 72 \mathrm{~h}$ after addition to the cells). RPTI, Rhizoma Pinelliae trypsin inhibitor. 
and incubated at $37^{\circ} \mathrm{C}$ for $5 \mathrm{~min}$. Then $2.50 \mathrm{ml}$ BAPNA solution was added and reacted at $37^{\circ} \mathrm{C}$ for $5 \mathrm{~min}$, the reaction was immediately terminated and added to $0.5 \mathrm{ml} 33 \%$ acetic acid solution, the absorbance (A) was detected at $410 \mathrm{~nm}$, with the test sample without inhibitor as the control sample. Table IV shows that at $0-2.5 \mu \mathrm{g} / \mathrm{ml}$ RPTI, the trypsin inhibition activity had a good linear association with the concentration of RPTI. The linear regression equation was $\mathrm{Y}=-25.709 \mathrm{X}+94.862$ $\left(\mathrm{R}^{2}=0.9626\right)$. The RPTI concentration required to completely inhibit $20 \mu \mathrm{g}$ of trypsin was $3.69 \mu \mathrm{g} / \mathrm{ml}$ and the inhibition ratio (mass) of RPTI to trypsin was 1:6.78, with a molar inhibition ratio of 1:1.69.

Inhibitory effect of RPTI on BGC-823 cell proliferation in vitro. Table $\mathrm{V}$ shows that RPTI significantly inhibited the proliferation of BGC-823 cells and that the inhibition was concentration-dependent. The $\mathrm{IC}_{50}$ of RPTI calculated using logistic regression was $16.96 \mu \mathrm{g} / \mathrm{ml}$ within $48 \mathrm{~h}$ after treatment and $9.61 \mu \mathrm{g} / \mathrm{ml}$ within $72 \mathrm{~h}$ after treatment.

The BGC-823 cells were treated with $10 \mu \mathrm{g} / \mathrm{ml}$ RPTI (Fig. 2). After $72 \mathrm{~h}$, the changes in cell shape were observed under an inverted microscope. The BGC- 823 cells in the RPTI group were less shrunken and were significantly reduced in number compared with those of the control group, with numerous suspended cells being dead. The cells exhibited nuclear pyknosis and rough cytoplasms and underwent less fission. The control cells had regular shapes and good adherent growth.

Activity of RPTI against BGC-823 cells in vivo. Table VI shows that subcutaneous RPTI administration around the tumour significantly inhibited the growth of the transplanted BGC-823 cells and the inhibition was dose-dependent. The tumour inhibition rates of the high-dose and medium-dose groups were significantly higher than that in the control group, but was lower than that of the CTX positive control group. The tumour inhibition effect in the low-dose group was not significantly different from that in the control group. RPTI was not observed to have a significant effect on the spleen coefficient of the mice.

\section{Discussion}

Pinellia ternata tuber is used for the clinical treatment of various neoplastic diseases alone or combined with other Chinese medicines (5-8). Studies have suggested that the Pinellia protein significantly inhibits the proliferation of ovarian cancer cells (11). TIs are widely present in plants and are widely accepted in the medical field as potential cancer preventive agents. In the present study, a small protein from Pinellia ternata tuber was isolated through separation methods, demonstrated that this component has certain trypsin inhibitory activity and inferred that RPTI may be a component of Pinellia ternata that has antitumour activity. To the best of our knowledge, the present study is the first to isolate and purify RPTI. The purified RPTI showed a single band under SDS-PAGE, with a molecular weight of $14 \mathrm{kDa}$. Its N-terminal amino acid sequence was DPVVDG, which is highly homologous to that of arrowhead serine proteinase inhibitors. The inhibition rate (mass) of RPTI to the trypsin activity was 1:6.78. RPTI markedly inhibited trypsin activity and its inhibition constant $\mathrm{Ki}$ was significantly lower than the
$\mathrm{Km}$ of trypsin (data not shown). Therefore, RPTI was considered as a strong serine proteinase inhibitor.

The present study preliminarily demonstrates that RPTI has a significant inhibitory effect on BGC-823 cell proliferation in vitro and on the tumour growth of transplanted BGC-823 cells. The tumour inhibition was concentration- and dose-dependent. Consequently, RPTI has significant antitumour activity. A key step in tumour cell growth and infection is extracellular matrix (ECM) degradation. RPTI likely exerts its antitumour effects by combining with the serine proteinase or a specific receptor on the external surface of BGC-823 cell membranes through different approaches. Thus, the proteinase loses its ability to hydrolyse the ECM, preventing BGC-823 cell invasion and tumour growth.

During the separation and purification of RPTI using affinity chromatography, the samples were maintained at $37^{\circ} \mathrm{C}$ for $1 \mathrm{~h}$ after loading. The column was then washed with a highly concentrated salt solution $(1 \mathrm{~mol} / 1 \mathrm{NaCl})$ to wash off the majority of nonspecific binding hybrid proteins. The bonding RPTI ingredients were eluted with aqueous acid so that the purity of the RPTI, separated through affinity chromatography with trypsin as the ligand, was significantly improved. The $P_{1}$ and $P_{2}$ activity peaks generated through Sephadex G-50 filtration were not completely separated and the ingredients in tubes 10-16 were detected to have clear TI activity. Only the first half of the $\mathrm{P}_{1}$ peak, i.e., the proteins in tubes 10-12, showed a uniform band in the SDS-PAGE. Following further electrophoresis and transmembrane separation, the main band of the purified RPTI ingredient was cut off for sequencing to ensure the purity of the RPTI.

The serine proteinase inhibitor separated from the tuber of Pinellia ternata has promising potential for application in antitumour therapy. The aim of further studies is to design degenerate primers according to the RPTI N-terminal amino acid sequence, clone its cDNA sequence, elucidate the complete gene expression of RPTI and determine its mechanism of action.

\section{References}

1. Zhao GP, Dai S and Chen RS: Dictionary of traditional Chinese medicine. Shanghai Scientific and Technical Publishers (Second Edition): 1071-1072, 2005.

2. Han MH, Yang XW, Zhong GY and Zhang M: Bioactive constituents inhibiting TNF-alpha production in fresh rhizome of Pinellia ternata. Zhongguo Zhong Yao Za Zhi 32: 1755-1759, 2007 (In Chinese).

3. He P, Li S, Wang SJ, Yang YC and Shi JG: Study on chemical constituents in rhizome of Pinellia ternata. Zhongguo Zhong Yao Za Zhi 30: 671-674, 2005 (In Chinese).

4. Lee MY, Shin IS, Jeon WY, Lim HS, Kim JH and Ha H: Pinellia ternata Breitenbach attenuates ovalbumin-induced allergic airway inflammation and mucus secretion in a murine model of asthma. Immunopharmacol Immunotoxicol 35: 410-418, 2013.

5. Li GL, Gui SQ and Wang L: Effect of pinellia extract on HeLa cell line in vitro and associated mechanism. Zhongguo Zhong Xi Yi Jie He Za Zhi 30: 303-307, 2010 (In Chinese).

6. Lin J, Yao J, Zhou X, Sun X and Tang K: Expression and purification of a novel mannose-binding lectin from Pinellia ternata. Mol Biotechnol 25: 215-222, 2003.

7. Xu T, Wang B, Wang L, Zhang Y and Lv Z: Pinellia ternata agglutinin produced in Bombyx mori cells exhibits bioactivity. Acta Biochim Pol 59: 231-236, 2012

8. Lu Q, Li N, Luo J, et al: Pinellia pedatisecta agglutinin interacts with the methylosome and induces cancer cell death. Oncogenesis 1: e29, 2012. 
9. Yoon JS, Seo JC and Han SW: Pinelliae Rhizoma herbal-acupuncture solution induced apoptosis in human cervical cancer cells, SNU-17. Am J Chin Med 34: 401-408, 2006.

10. Li GL, Jiang W, Xia Q, et al: HPV E6 down-regulation and apoptosis induction of human cervical cancer cells by a nove lipid-soluble extract (PE) from Pinellia pedatisecta Schott in vitro. J Ethnopharmacol 132: 56-64, 2010.

11. Chen XY, Zhou L and Zheng FY: Proteomica study of total protein of Pinellia pedactisecta Schott effect on human ovarian cancer SKOV3 cells. Zhongguo Zhong Xi Yi Jie He Za Zhi 31: 1651-1656, 2011 (In Chinese).

12. Zhou W, Huang Y, Xu S, et al: Prokaryotic expression and bioactivity analysis of $\mathrm{N}$-terminus domain of Pinellia ternata agglutinin using alkaline phosphatase signal peptide. Protein Expr Purif 89: 84-91, 2013.

13. Sierko E, Wojtukiewicz MZ, Zimnoch L, et al Protein Z/protein Z-dependent protease inhibitor system in human non-small-cell lung cancer tissue. Thromb Res 129: e92-e96, 2012.

14. Sierko E, Wojtukiewicz MZ, Zimnoch L, Tokajuk P, Ostrowska-Cichocka K and Kisiel W: Co-localization of Protein Z, Protein Z-Dependent protease inhibitor and coagulation factor $X$ in human colon cancer tissue: implications for coagulation regulation on tumor cells. Thromb Res 129: e112-e118, 2012

15. Sun L, Niu L, Zhu X, Hao J, Wang P and Wang H: Antitumour effects of a protease inhibitor, nelfinavir, in hepatocellular carcinoma cancer cells. J Chemother 24: 161-166, 2012.

16. Tamburino R, Pizzo E, Sarcinelli C, et al: Enhanced cytotoxic activity of a bifunctional chimeric protein containing a type 1 ribosome-inactivating protein and a serine protease inhibitor. Biochimie 94: 1990-1996, 2012.

17. Gocho T, Uwagawa T, Furukawa K, et al: Combination chemotherapy of serine protease inhibitor nafamostat mesilate with oxaliplatin targeting NF- $\mathrm{\kappa B}$ activation for pancreatic cancer. Cancer Lett 333: 89-95, 2013.

18. Morjen M, Kallech-Ziri O, Bazaa A, et al: PIVL, a new serine protease inhibitor from Macrovipera lebetina transmediterranea venom, impairs motility of human glioblastoma cells. Matrix Biol 32: 52-62, 2013.

19. Kobayashi H, Gotoh J, Hirashima $Y$ and Terao $T$ : Inter-alpha-trypsin inhibitor bound to tumor cells is cleaved into the heavy chains and the light chain on the cell surface. J Biol Chem 271: 11362-11367, 1996.
20. Baba T, Kawaguchi M, Fukushima T, et al: Loss of membrane-bound serine protease inhibitor HAI-1 induces oral squamous cell carcinoma cells' invasiveness. J Pathol 228: 181-192, 2012.

21. Brandi G, Tavolari S, De Rosa F, et al: Antitumoral efficacy of the protease inhibitor gabexate mesilate in colon cancer cells harbouring KRAS, BRAF and PIK3CA mutations. PLoS One 7: e41347, 2012

22. Chen DY, Lee Y, Van Tine BA, et al: A pharmacologic inhibitor of the protease Taspasel effectively inhibits breast and brain tumor growth. Cancer Res 72: 736-746, 2012.

23. Magee PJ, Owusu-Apenten R, McCann MJ, Gill CI and Rowland IR: Chickpea (Cicer arietinum) and other plant-derived protease inhibitor concentrates inhibit breast and prostate cancer cell proliferation in vitro. Nutr Cancer 64: 741-748, 2012.

24. Palavalli MH, Natarajan SS, Wang TT and Krishnan HB: Imbibition of soybean seeds in warm water results in the release of copious amounts of Bowman-Birk protease inhibitor, a putative anticarcinogenic agent. J Agric Food Chem 60: 3135-3143, 2012.

25. Rengan R, Mick R, Pryma D, et al: A phase I trial of the HIV protease inhibitor nelfinavir with concurrent chemoradiotherapy for unresectable stage IIIA/IIIB non-small cell lung cancer: a report of toxicities and clinical response. J Thorac Oncol 7: 709-715, 2012

26. Shim JS, Rao R, Beebe K, et al: Selective inhibition of HER2-positive breast cancer cells by the HIV protease inhibitor nelfinavir. J Natl Cancer Inst 104: 1576-1590, 2012.

27. Loewenberg JR: Cyanide and the determination of protein with the Folin phenol reagent. Anal Biochem 19: 95-97, 1967.

28. Al-Tubuly AA: SDS-PAGE and western blotting. Methods Mol Med 40: 391-405, 2000

29. Edman P, Högfeldt E, Sillén LR, Kinell P-O: Method for determination of the amino acid sequence in peptides. Acta Chemica Scandinavica 4: 283-293, 1950

30. Dudai M, Mayer M and Kidron M: Protease inhibitor activity in rat skeletal muscle. Hoppe Seylers Z Physiol Chem 363: 651-654, 1982.

31. Berg K, Hansen MB and Nielsen SE: A new sensitive bioassay for precise quantification of interferon activity as measured via the mitochondrial dehydrogenase function in cells (MTT-method). APMIS 98: 156-162, 1990. 